\title{
Three new Pimelodus species (Siluriformes: Pimelodidae) from the rio Tocantins drainage, Brazil
}

\author{
Frank R.V. Ribeiro ${ }^{1}$, Carlos A. S. Lucena ${ }^{2}$ and Paulo H. F. Lucinda ${ }^{3}$
}

Three new species of Siluriformes from the rio Tocantins drainage of Brazil are placed in the genus Pimelodus, P. stewarti, $P$. joannis, and P. halisodous. Pimelodus halisodous differs from the sympatric P. joannis and P. stewarti by the number of premaxillary tooth rows (13-16 vs. 5-9). Pimelodus joannis differs from $P$. stewarti by the presence of two dark blotches on the base of the caudal fin. The three new species differ from all other species of Pimelodus by the possession of a uniform gray coloration along flanks; the relatively short distance between the posterior nostril and the anterior orbital border; a short maxillary barbel, that only slightly surpasses the caudal-fin base.

Três espécies novas de Siluriformes da bacia do rio Tocantins são alocadas no gênero Pimelodus: P. stewarti, P. joannis e $P$. halisodous. Pimelodus halisodous difere das espécies simpátricas $P$.joannis e $P$. stewarti pelo número de fileiras de dentes do pré-maxilar (13-16 vs. 5-9). Pimelodus joannis difere de $P$. stewarti pela presença de duas manchas negras na base na nadadeira caudal. As três novas espécies diferem das demais espécies de Pimelodus pela coloração cinza uniforme ao longo dos flancos; curta distância entre a narina posterior e a margem anterior da orbita; e barbilhões maxilares curtos, ultrapassando levemente a base da nadadeira caudal.

Key words: Catfish, Taxonomy, South America, Neotropical Region.

\section{Introduction}

The catfish family Pimelodidae encompasses 29 genera and 94 species distributed exclusively in the Neotropical Region from Panama to Argentina (Lundberg \& Littmann, 2003; Ferraris, 2007; Eschmeyer, 2007). The most speciose pimelodid genus is Pimelodus, which consists of 29 species. A cladistic diagnosis of the genus Pimelodus is still lacking, so that a non-cladistic definition has been employed from the latter part of the $19^{\text {th }}$ century to the present. The first wide-ranging revision of Pimelodus was conducted by Eigenmann \& Eigenmann (1890). Those authors defined the genus on the basis of dental characters, fontanel length, width of posterior cleithral process, and the number of dorsal-fin rays.

Examination of the collection of pimelodid fishes housed at the Laboratório de Ictiologia Sistemática, Universidade Federal do Tocantins revealed the existence of three undescribed pimelodid species from the rio Tocantins drainage, which fit into Eigenmann \& Eigenmann's (1890) diagnosis of Pimelodus. The purpose of this paper is to name and formally describe these species.

\section{Material and Methods}

Measurements and counts follow Lundberg \& McDade (1986) and Lundberg et al. (1991b) with the modifications of Lundberg \& Parisi (2002) and Ribeiro \& Lucena (2006a). Examined specimens belong to the Academy of Natural Sciences, Philadelphia (ANSP), Field Musem of Natural History, Chicago (FMNH), Museu de Ciências e Tecnologia, Pontifícia Universidade Católica do Rio Grande do Sul, Porto Alegre (MCP), Museu de Zoologia da Universidade Estadual de Londrina, Londrina (MZUEL), Museu de Zoologia da Universidade de São Paulo, São Paulo (MZUSP), Laboratório de Ictiologia Sistemática da Universidade Federal do Tocantins, Porto Nacional (UNT), and Departamento de Zoologia de Vertebrados de la Facultad de Humanidades y Ciencias, Montevideo (ZVC-P). Counts and measurements were made on the left side of specimens whenever possible. Measurements are straight-line distances taken point-to-point with digital calipers to the nearest $0.1 \mathrm{~mm}$. All measurements are expressed as percent of standard length (SL), except subunits of the head, which are expressed as percent of head

${ }^{1}$ Programa de Coleções e Acervos Científicos, Instituto Nacional de Pesquisas da Amazônia, Caixa Postal 478, 69011-970 Manaus, AM, Brazil. fraynner@yahoo.com.br

${ }^{2}$ Setor de Peixes, Museu de Ciências e Tecnologia, Pontifícia Universidade Católica do Rio Grande do Sul, Av. Ipiranga 6681, 90619-900 Porto Alegre, RS, Brazil. lucena@pucrs.br

${ }^{3}$ Laboratório de Ictiologia Sistemática, Universidade Federal do Tocantins, Campus de Porto Nacional. Rua 3, Quadra 17 s/n - Jardim dos Ipês, Caixa Postal 136, 77500-000 Porto Nacional, TO, Brazil. lucinda@uft.edu.br (corresponding author) 


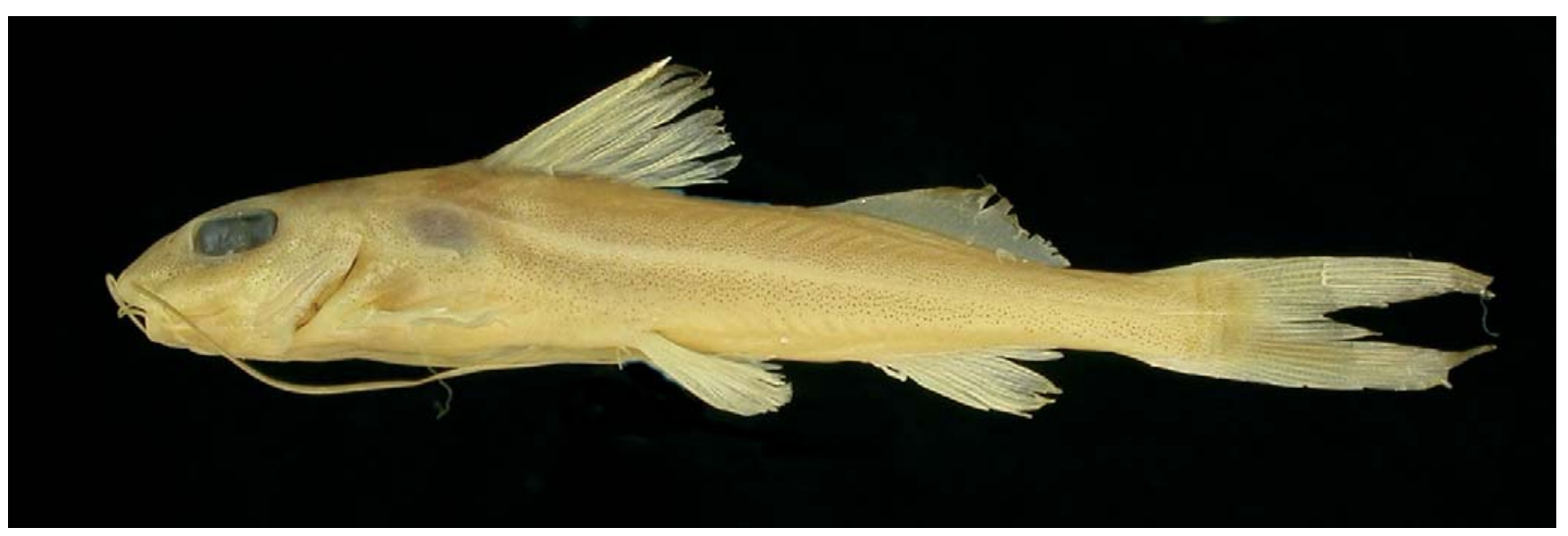

Fig. 1. Pimelodus stewarti, holotype, MCP 41737, $54.1 \mathrm{~mm} \mathrm{SL}$, rio Paranã, rio Tocantins drainage, Brazil.

length (HL). Fin-ray counts include all rays. The two posterior most anal-fin rays that are inserted at same pterygiophore were counted as a single element. Gill rakers were counted on the first branchial arch (ceratobranchial and epibranchial). Osteological preparations were cleared and counterstained for cartilage and bone using the method of Taylor \& Van Dyke (1985). Tooth rows, branchiostegal rays, procurrent caudal-fin rays and vertebral counts were taken from cleared and stained specimens (c\&s). In vertebral counts the fused $\mathrm{PU} 1+\mathrm{U} 1$ is considered as a single bone, and the Weberian apparatus as having five elements. Osteological terminology follows Lundberg \& Luckenbill (2007). Comparative material is that listed by Ribeiro \& Lucena (2006a, 2006b, 2007) and additional specimens listed below under "Additional Examined Specimens".

\section{Results}

\section{Pimelodus stewarti, new species}

Fig. 1

Pimelodus sp. B - Lucinda et al., 2007: 79.

Holotype. MCP 41737, 54.1 mm SL, rio Paranã, near lagoa Verde, approximately $12^{\circ} 30^{\prime} \mathrm{S} 48^{\circ} 12^{\prime} \mathrm{W}$, Paranã, Tocantins, Brazil, 8 Jul 2000, Neamb-UFT.

Paratypes. Brazil. Tocantins State. All collected by Neamb-UFT staff. MCP 41920, 5, 38.4-40.6 mm SL, and UNT 5642, 38 (1 c\&s), 35.0-50.8 mm SL, Ipueiras, rio Tocantins near rio Manoel Alves, approximately $11^{\circ} 19^{\prime} \mathrm{S} 48^{\circ} 28^{\prime} \mathrm{W}, 20$ Jan 2000 . UNT 5649 , 2, 60.6-60.5 mm SL, Paranã, rio Paranã, approximately $12^{\circ} 30^{\prime} \mathrm{S}$ 48 12'W, 7 Jan 2001. UNT 5748, 1, 61.7 mm SL, Paranã, rio Paranã, approximately $12^{\circ} 29^{\prime} \mathrm{S} 48^{\circ} 12^{\prime} \mathrm{W}, 8$ Feb 2000 . UNT 5754, 8, 44.4$48.8 \mathrm{~mm}$ SL, Porto Nacional, rio Tocantins, $10^{\circ} 43^{\prime} 15^{\prime \prime S} 48^{\circ} 25^{\prime} 14^{\prime \prime} \mathrm{W}$, 23 Mar 2000. UNT 5756, 2, 47.8-48.0 mm SL, São Salvador, rio Maranhão, approximately $12^{\circ} 45^{\prime} \mathrm{S} 48^{\circ} 48^{\prime} \mathrm{W}, 10 \mathrm{Mar} 2005$. UNT 5766, 2, 44.8-49.8 mm SL, Porto Nacional, rio Tocantins, 1043'15"S 48²5'14"W, 24 Mar 2000. UNT 5798, 1, 40.2 mm SL, Pedro Afonso, rio Tocantins, approximately $08^{\circ} 59^{\prime}$ 'S 48¹0'W, 15 Jan 2001. UNT 5801, 1, $43.2 \mathrm{~mm} \mathrm{SL}$, Porto Nacional, rio Tocantins, $10^{\circ} 43^{\prime} 15^{\prime \prime S ~ 48} 25^{\prime} 14^{\prime \prime W}, 24$ Feb 2000. UNT 5856, 3, 58.6-66.1 $\mathrm{mm} \mathrm{SL}$, collected with the holotype.
Diagnosis. Pimelodus stewarti is distinguished from its congeners, except $P$. halisodous, $P$. joannis, $P$. ornatus and $P$. pictus, by the presence of a dark spot in the distal portion of dorsal-fin rays 2-4 ( $v s$. absence of such spot); dark transverse band just anterior to dorsal fin (vs. absence of such band); shorter distance between the posterior nostril and the anterior orbital border (posterior nostril closer to anterior orbital border $v s$. posterior nostril closer to anterior nostril than to anterior orbital border). Pimelodus stewarti differs from $P$. ornatus and $P$. pictus by its uniform gray coloration along the flanks, and a light narrow band along the lateral line ( $v s$. two bands or dark dots along flanks, respectively). Pimelodus stewarti differs from $P$. joannis by having a greater posterior cleithral-process length (12.7-15.6 vs. 10.2-12.4\% of SL) and by the absence of dark blotches on the caudal-fin base ( $v s$. two dark blotches) and from $P$. halisodous by a smaller pectoral-spine length (15.4-19.6 vs. 20.0-23.5\% of SL); a shorter snout (36.1-40.9 vs. 43.1-47.9\% of HL); and by having fewer rows of premaxillary teeth (5-8 vs. 13-16).

Description. Morphometric data in Table 1. Body deeper than wide. Dorsal profile of body convex from snout tip to supraoccipital process origin, straight from that region to dorsal-fin origin; straight from dorsal insertion to adipose-fin origin, then gently sloping to anterior extent of caudal peduncle. Dorsal and ventral profiles of caudal peduncle slightly concave. Ventral profile of head anterior to isthmus straight. Preventral profile of body slightly convex or straight. Anal-fin base straight. Head covered by thin skin. Skull roof ornamented with numerous small granulations and osseous tubercles, more visible in larger specimens. Snout not very long, projecting beyond mandibular symphysis by distance less than internarial length. Mouth subterminal; margins curved in ventral view when mouth closed and exposing approximately anterior half of premaxillary tooth rows. Upper lip thick, fleshy, not striated. Lower lip posterior to vertical passing through anterior margin of anterior nostril. Fleshy rictal fold in pocket behind corner of mouth. Posterior nostril closer to anterior orbital margin than to anterior nostril. Anterior nostril with fleshy rim slightly raised posteriorly; posterior nostril thin, fleshy, rim anteriorly elevated. 
Eye large, elliptical, margin completely free and dorsolaterally positioned on head; horizontal orbital diameter greater than interorbital width orbit oblong, horizontal orbital diameter greater than vertical orbital diameter. Premaxillary tooth patch short, broad, rectangular and transversely elongated; internal border of premaxillary tooth plate straight or slightly concave; premaxilla with eight irregular rows of slender conical teeth; 58 tooth rows on dentary $(n=10)$. Vomerine and pterygoid tooth plates absent. Anterior cranial fontanel triangular in dorsal view, open from mesethmoid to frontals, and terminating before vertical through posterior margin of eye. Posterior cranial fontanel ovoid or circular, foramen in center of supraoccipital. Supraoccipital process wide; dorsal surface rounded, ornamented with numerous small granulations; lateral margins of supraoccipital process converging posteriorly, process covered by narrow sheath of opaque hyaline skin. Anterior nuchal plate with short anterior process fitting into bifid supraoccipital tip. Anterior and middle nuchal plates ornamented sparsely with tuberculated ridges. Posterior nuchal plate with long posterior process trespassing line through origin of first branched dorsal-fin ray. Three pairs of barbels, flattened at base. Maxillary barbel inserted at vertical through anterior edge of lower lip; slightly surpassing anal-fin base. Mental barbels inserted in advance of gular fold apex, in curved line parallel to mandibular margin. Inner mental barbel reaching base of pectoral fin. Tip of outer mental barbel reaching tips of middle pectoral-fin rays, almost

Table 1. Morphometric data of Pimelodus stewarti. Range includes the holotype $(\mathrm{H})$.

\begin{tabular}{|c|c|c|c|c|c|}
\hline Measurements & $\mathrm{H}$ & $\mathrm{n}$ & low & high & $\overline{\text { mean }}$ \\
\hline Standard length $(\mathrm{mm})$ & 54.1 & 21 & 40.2 & 66.1 & 44.0 \\
\hline \multicolumn{6}{|c|}{ Percents of standard length } \\
\hline Predorsal length & 35.9 & 21 & 35.5 & 38.3 & 36.6 \\
\hline Preanal length & 72.5 & 21 & 71.6 & 74.8 & 72.7 \\
\hline Head length & 25.0 & 21 & 24.8 & 28.3 & 26.3 \\
\hline Caudal-peduncle length & 18.5 & 21 & 14.9 & 18.5 & 16.7 \\
\hline Caudal-peduncle depth & 7.4 & 21 & 7.1 & 7.9 & 7.5 \\
\hline Adipose-fin length & 26.4 & 21 & 23.3 & 28.6 & 25.7 \\
\hline Adipose-fin height & 5.4 & 21 & 4.8 & 7.4 & 6.4 \\
\hline $\begin{array}{l}\text { End of dorsal-fin base to origin of } \\
\text { adipose-fin distance }\end{array}$ & 14.4 & 21 & 11.5 & 16.7 & 13.8 \\
\hline Anal-fin base length & 13.3 & 21 & 11.3 & 14.9 & 13.2 \\
\hline Anal-fin length & 13.7 & 21 & 13.4 & 17.2 & 15.2 \\
\hline Pelvic-fin length & 12.4 & 21 & 12.4 & 15.8 & 14.1 \\
\hline Dorsal-fin length & 19.6 & 21 & 19.6 & 24.1 & 21.4 \\
\hline $\begin{array}{l}\text { Urogenital papilla to anal-fin-base } \\
\text { origin distance }\end{array}$ & 14.0 & 20 & 12.6 & 16.2 & 14.2 \\
\hline Dorsal-spine length & 20.1 & 21 & 19.0 & 24.1 & 21.1 \\
\hline Pectoral-spine length & 17.0 & 21 & 15.4 & 19.6 & 17.9 \\
\hline Body depth & 19.0 & 21 & 17.5 & 19.0 & 18.3 \\
\hline Body width & 17.0 & 21 & 15.9 & 18.3 & 17.1 \\
\hline Posterior cleithral-process length & 13.9 & 21 & 12.7 & 15.6 & 13.9 \\
\hline \multicolumn{6}{|c|}{ Percents of head length } \\
\hline Head depth & 67.4 & 21 & 59.9 & 67.4 & 63.0 \\
\hline Interorbital width & 20.0 & 21 & 15.2 & 21.0 & 18.7 \\
\hline Snout length & 38.5 & 21 & 36.1 & 40.9 & 38.6 \\
\hline Internarial length & 20.7 & 21 & 19.5 & 22.9 & 21.0 \\
\hline Anterior internarial width & 14.8 & 21 & 12.6 & 16.6 & 14.5 \\
\hline Posterior internarial width & 25.9 & 21 & 21.3 & 25.9 & 23.4 \\
\hline Horizontal eye diameter & 35.6 & 21 & 31.1 & 36.7 & 34.5 \\
\hline Mouth width & 31.9 & 21 & 31.5 & 36.1 & 33.7 \\
\hline Supraoccipital width & 25.2 & 21 & 20.4 & 26.2 & 23.1 \\
\hline Supraoccipital length & 28.9 & 21 & 26.1 & 31.7 & 28.2 \\
\hline
\end{tabular}

to tip of pectoral spine. Gill membranes free, diverging just behind gular fold apex and supported by 7 branchiostegal rays. Gill rakers well-ossified, sharp and slender; $12-17($ mode $=14)$ on first branchial arch; 2-4 on epibranchial ( $\operatorname{mode}=3), 10-13$ on ceratobranchial $($ mode $=12 ; \mathrm{n}=61)$. Dorsal fin rays II,6-7 (mode $=6 ; n=63$ ), fin inserted near anterior one-third of SL; its origin slightly posterior to vertical through tip of posterior cleithral process. Spinelet narrow, sharply angular or low crest in front. Dorsal spine straight, strong, pungent, shorter than first branched ray, continued in filamentous ray reaching nearly edge of first soft dorsal-fin ray; approximately as long as pectoral spine length. Dorsal spine with 1-3 anterior distal serrae $(n=12)$. Posterior margin of dorsal spine moderate sharp retrorse spines distally, becoming gradually erect near spine base. First branched dorsal-fin ray longest, last dorsal-fin ray slightly longer than one-half length of first ray; distal margin of dorsal fin nearly straight. Adipose fin large, posterior to middle of body. Adipose-fin margin rounded and moderately deep, its apex near to vertical through base of rays 4-6 of anal fin, ending posteriorly as short free lobe slightly posterior to vertical through tip of last anal-fin ray. Caudal fin i,7,8,i ( $(n=63) ; 20$ dorsal and 15 ventral procurrent caudal-fin rays; fin deeply forked, with pointed lobes; dorsal lobe slightly longer than ventral lobe, outer principal rays non-filamentous. Anal fin inserted on posterior one-third of SL; fin margin concave, not forming distinct lobe anteriorly; tips of three longest anterior and posterior branched rays meet when depressed. Anal fin ivvi,7-8 (mode $=8 ; \mathrm{n}=63$ ), last rays simple, first and second branched rays longest. Pectoral fin i, $8-9$ (mode $=9 ; n=63$ ); its posterior margin obliquely truncate, first soft ray longer than spine tip. Pectoral spine strong, distally pointed, dorsal and ventral surfaces smooth; numerous, regularly spaced, uniformly retrorse unicuspid dentations along posterior margin; antrorse and straight dentations along anterior margin, becoming progressively less prominent and more crowded proximally; anterior dentations much larger in juveniles. Pelvic fin i,5 $(n=10)$; first branched ray almost same length of last branched ray; first branched ray longest, inserted near vertical through last dorsal-fin ray. Lateral-line canal complete, extending onto caudal-fin base; canal nearly straight, with superficial tubular ossicles directed posteroventrally and more developed anteriorly; no accessory laterosensory canals posterior to nuchal area. Posterior cleithral process broad, narrowing posteriorly; ventral margin nearly straight, dorsal margin somewhat concave; granular osseous tubercles on lateral surface. Urogenital papilla short, located in shallow depression immediately posterior of anus. No apparent sexual dimorphism. Superficial ossifications of Weberian complex centrum not covering seventh centrum. Total vertebrae 40 ( 15 precaudal and 25 caudal). First pleural rib on sixth vertebra. Ten pairs of pleural ribs.

Color in alcohol. Body light brownish to yellow, with white unpigmented stripe on lateral line. Ventral region light to yellowish. Head surface with blackish area on supraoccipital process. Eye dark. Dark transverse band just anterior to dorsal fin. Several dark chromatophores on posterior cleithral process, 
opercle and below orbital region. Dark spot on distal portion of second to fourth branched dorsal-fin rays. Pectoral, pelvic, and anal fins hyaline. Black chromatophores along interradial membranes of caudal fin, mainly concentrated on median portion of ventral lobe. Adipose fin with few black chromatophores scattered on distal surface. Maxillary barbel dusky on dorsal surface; lighter on ventral surface. Mental barbels pale.

Distribution. Pimelodus stewarti is known from the upper and middle portions of the rio Tocantins drainage (Fig. 2).

Etymology. The specific epithet stewarti is a patronym for Donald Stewart, in recognition of his many contributions to catfish systematics.

\section{Pimelodus halisodous, new species}

Fig. 3

Pimelodus sp. D - Lucinda et al., 2007: 79

Holotype. MCP 41738, $108.8 \mathrm{~mm}$ SL, rio Paranã, $12^{\circ} 30^{\prime} \mathrm{S} 48^{\circ} 12^{\prime} \mathrm{W}$, fazenda Traçadal, Paranã, Tocantins, Brazil, 9 May 2000, NeambUFT.

Paratypes. Brazil. Tocantins State. All collected by Neamb-UFT staff. MCP 41921, 2, 99.5-101.2 mm SL, UNT 3438, 2 (1 c\&s), 98.9-103.9 mm SL, Porto Nacional, rio Tocantins, $10^{\circ} 43^{\prime} 15^{\prime \prime S}$ 48 25'14"W, 14 Jan 1997. UNT 3443, 1, 107.0 mm SL, Paranã, fazenda Traçadal, rio Paranã, 12³0'S 48¹2'W, 25 Mar 1998. UNT 3449 , 1, 98.7 mm SL, Brejinho de Nazaré, rio Tocantins, 1059'46"S $48^{\circ} 32^{\prime} 06^{\prime \prime W}, 4$ Nov 2002. UNT 3450, 1, $110.7 \mathrm{~mm} \mathrm{SL}$, collected with the holotype. UNT 3452, 1, $96.5 \mathrm{~mm} \mathrm{SL}$, Porto Nacional, rio Tocantins, $10^{\circ} 43^{\prime} 15^{\prime \prime S} 48^{\circ} 25^{\prime} 14^{\prime \prime} \mathrm{W}, 10$ Jun 2002. UNT 3455, 1, 99.2 $\mathrm{mm}$ SL, Porto Nacional, rio Tocantins, 1043'15"S 48²5'14"W, 18 Dec 1997. UNT 3899, 1, $106.2 \mathrm{~mm}$ SL, Pedro Afonso, rio Sono, approximately $8^{\circ} 59^{\prime} \mathrm{S} 48^{\circ} 10^{\prime} \mathrm{W}, 20$ Feb 2001. UNT 3900, 2, 88.6 and $84.8 \mathrm{~mm}$ SL, Porto Nacional, rio Tocantins, $10^{\circ} 43^{\prime} 15^{\prime \prime S} 48^{\circ} 25^{\prime} 14^{\prime \prime} \mathrm{W}$, 4 Dec 2002. UNT 5837, 1, 103.0 mm SL, Paranã, fazenda Traçadal, rio Tocantins, approximately $1^{\circ} 29^{\prime} \mathrm{S} 48^{\circ} 12^{\prime} \mathrm{W}, 29$ Sep 1999.

Diagnosis. Pimelodus halisodous is distinguished from its congeners, except $P$. jivaro, $P$. joannis, $P$. ornatus, $P$. pictus, and $P$. stewarti, by the presence of a dorsal median crest along supraoccipital process ( $v s$. crest absent); and shorter distance between the posterior nostril and the anterior orbital border (posterior nostril closer to anterior orbital border $v s$. posterior nostril closer to anterior nostril than to anterior orbital border). Pimelodus halisodous differs from P. jivaro by the shorter maxillary barbel, extending only slightly beyond caudal-fin base ( $v s$. maxillary barbel surpassing total length). The new species differs from $P$. ornatus and $P$. pictus by the uniform grayish to yellowish coloration ( $v s$. presence of two bands or dark dots along flanks, respectively). Pimelodus halisodous differs from $P$. stewarti and $P$. joannis by having a longer pectoral-fin spine (20.0-23.5 vs. 15.4-19.6\% SL); a longer snout (43.1-47.9 vs. 35.8-41.8\% HL); and a larger number of premaxillary tooth rows (13-16 vs. 5-9).
Description. Morphometric data on Table 2. Body deeper than wide. Dorsal profile of body convex along snout, straight from orbital region to dorsal-fin origin, dorsal insertion to adiposefin origin gently sloping to anterior extent of caudal peduncle. Dorsal and ventral profiles of caudal peduncle slightly concave. Ventral profile of head straight to anterior region of isth-

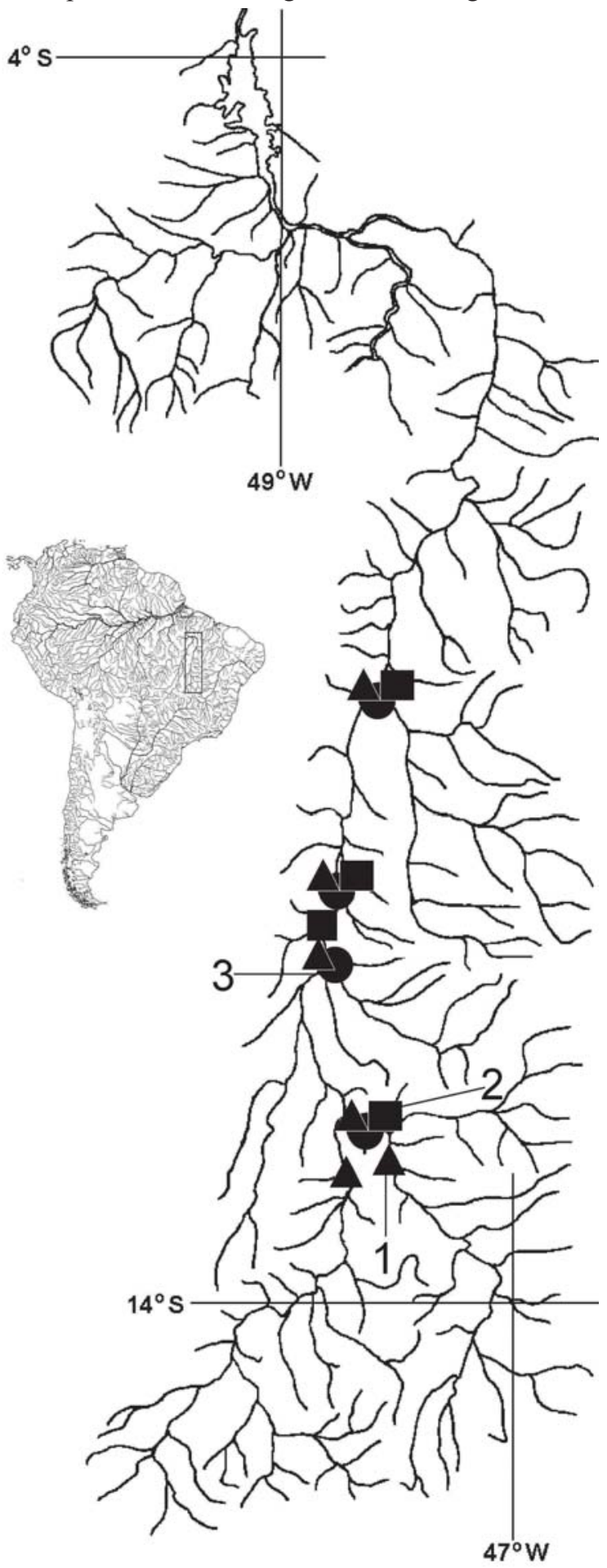

Fig. 2. Rio Tocantins drainage showing the collection localities of Pimelodus stewarti (triangles, 1), P. halisodous (squares, 2 ), and $P$. joannis (circles, 3 ). Numbers represent type-localities. Some symbols represent more than one lot or locality. 


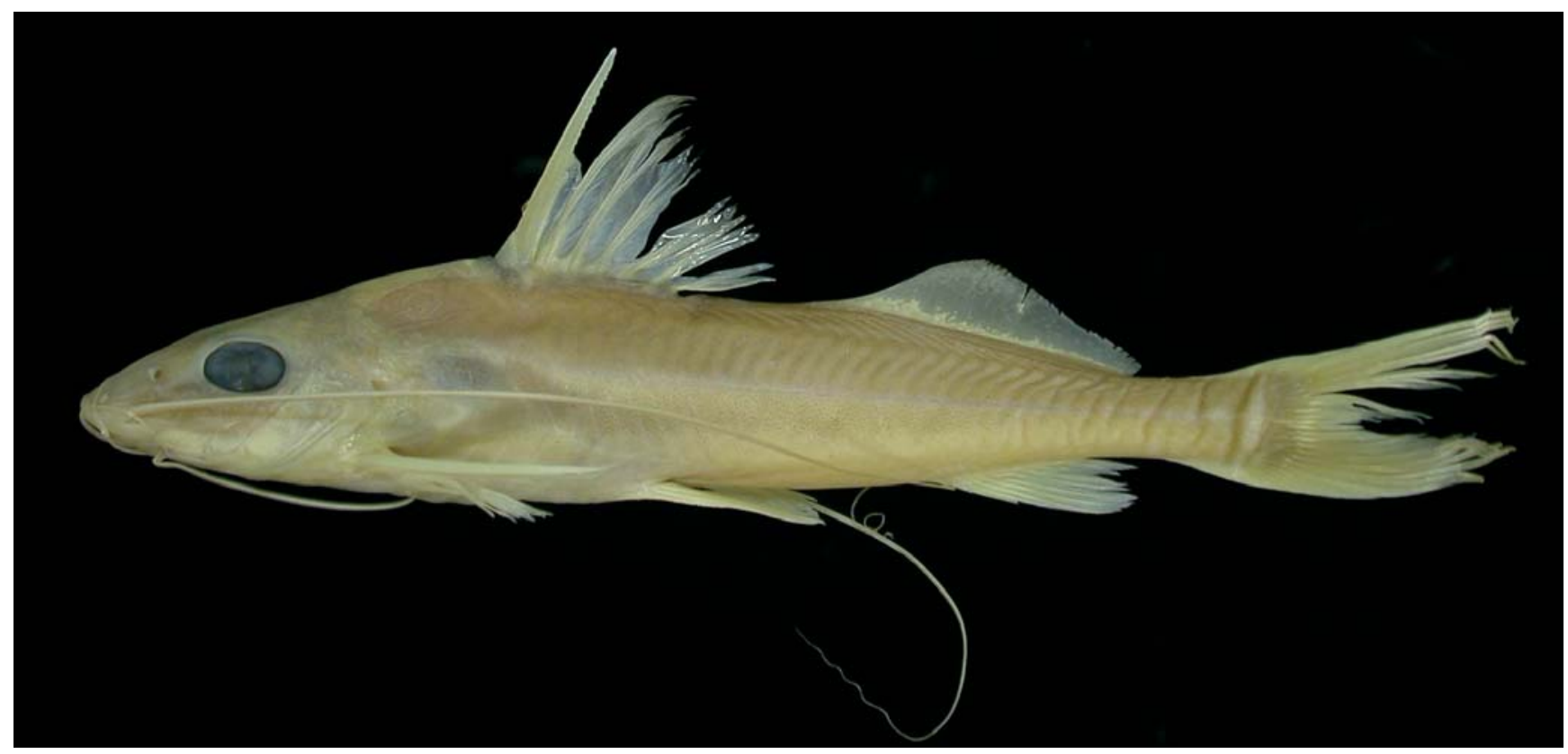

Fig. 3. Pimelodus halisodous, holotype, MCP 41738, 108.8 mm SL, rio Paranã, rio Tocantins drainage, Brazil.

mus; preventral profile of body slightly convex; anal-fin base straight. Head covered by thin skin. Skull roof ornamented with numerous small granulations, more visible in larger specimens. Snout not very long, projecting beyond mandibular symphysis by distance less than internarial length. Mouth subterminal; margins curved in ventral view when mouth closed and exposing less than anterior half of premaxillary tooth rows; upper lip thick, fleshy, striated. Fleshy rictal fold in pocket behind corner of mouth. Posterior nostrils closer to anterior orbital border than to anterior nostrils; anterior nostril with fleshy rim slightly raised posteriorly; posterior nostril thin, fleshy, with elevated rim. Eye large, elliptical, margin completely free and dorsolaterally positioned on head; horizontal orbital diameter greater than interorbital width; orbit oblong, horizontal orbital diameter greater than vertical orbital diameter. Premaxillary tooth patch short, broad, rectangular and transversely elongated; premaxilla with approximately $13-16(n=8)$ irregular rows of slender conical teeth; internal border of pre-maxilla concave. Four or five irregular tooth rows on dentary. Vomerine and pterygoid teeth plates absent. Anterior cranial fontanel triangular in dorsal view, open from mesethmoid to frontals, and terminating anterior to vertical through posterior margin of eye. Posterior cranial fontanel reduced to ovoid or circular foramen in center of supraoccipital in specimens smaller than $100 \mathrm{~mm}$ SL, and completely closed in larger specimens. Supraoccipital process wide; dorsal surface with longitudinal median crest, ornamented with numerous small granulations; lateral margins of supraoccipital process converging posteriorly, process covered by narrow sheath of opaque hyaline skin. Anterior and middle nuchal plates ornamented sparsely with tuberculated ridges. Anterior nuchal plate with short anterior process fitting into bifid supraoccipital tip. Posterior nuchal plate with short posterior process not trespassing line through origin of first branched dorsal-fin ray. Three pairs of barbels, each flattened at base. Maxillary barbel inserted at vertical through posterior edge of anterior nostril; slightly surpassing caudal-fin base. Mental barbels inserted anterior to gular fold apex, in curved line parallel to mandibular margin. Inner mental barbel reaching

Table 2. Morphometric data of Pimelodus halisodous. Range includes the holotype $(\mathrm{H})$.

\begin{tabular}{|c|c|c|c|c|c|}
\hline Measurements & $\overline{\mathrm{H}}$ & $\mathrm{n}$ & low & high & mean \\
\hline Standard length (mm) & 108.8 & 13 & 84.8 & 110.7 & 100.6 \\
\hline \multicolumn{6}{|c|}{ Percents of standard length } \\
\hline Predorsal length & 37.7 & 13 & 37.2 & 39.1 & 38.0 \\
\hline Preanal length & 75.5 & 13 & 71.4 & 75.9 & 74.4 \\
\hline Head length & 24.8 & 13 & 24.3 & 26.1 & 25.2 \\
\hline Caudal-peduncle length & 14.3 & 13 & 14.2 & 17.3 & 15.9 \\
\hline Caudal-peduncle depth & 6.8 & 13 & 6.5 & 7.2 & 6.9 \\
\hline Adipose-fin length & 29.3 & 13 & 27.2 & 32.4 & 29.9 \\
\hline Adipose-fin height & 6.5 & 13 & 5.1 & 7.0 & 5.9 \\
\hline $\begin{array}{l}\text { End of dorsal-fin base to origin of } \\
\text { adipose-fin distance }\end{array}$ & 12.2 & 13 & 8.9 & 12.5 & 10.7 \\
\hline Anal-fin base length & 11.7 & 13 & 10.3 & 12.1 & 11.2 \\
\hline Anal-fin length & 14.2 & 13 & 13.4 & 16.2 & 14.4 \\
\hline Pelvic-fin length & 15.5 & 13 & 14.0 & 16.9 & 15.1 \\
\hline Dorsal-fin length & 21.0 & 10 & 19.4 & 22.5 & 21.3 \\
\hline $\begin{array}{l}\text { Urogenital papilla to anal-fin-base origin } \\
\text { distance }\end{array}$ & 15.3 & 13 & 13.9 & 16.6 & 15.1 \\
\hline Dorsal-spine length & 22.0 & 8 & 20.3 & 23.8 & 22.4 \\
\hline Pectoral-spine length & 21.0 & 9 & 20.0 & 23.5 & 21.5 \\
\hline Body depth & 21.0 & 13 & 17.9 & 24.1 & 21.7 \\
\hline Body width & 17.7 & 13 & 16.9 & 18.9 & 17.9 \\
\hline Posterior cleithral-process length & 12.3 & 13 & 10.8 & 12.7 & 11.7 \\
\hline \multicolumn{6}{|c|}{ Percents of head length } \\
\hline Head depth & 65.6 & 13 & 62.0 & 70.2 & 65.4 \\
\hline Interorbital width & 21.5 & 13 & 18.2 & 22.2 & 20.2 \\
\hline Snout length & 44.4 & 13 & 43.1 & 47.9 & 45.2 \\
\hline Internarial length & 19.3 & 13 & 18.1 & 21.4 & 19.4 \\
\hline Anterior internarial width & 14.8 & 13 & 13.4 & 15.6 & 14.7 \\
\hline Posterior internarial width & 23.0 & 13 & 22.3 & 25.0 & 23.3 \\
\hline Horizontal eye diameter & 31.1 & 13 & 27.8 & 32.8 & 30.7 \\
\hline Mouth width & 29.3 & 13 & 28.2 & 36.9 & 32.6 \\
\hline Supraoccipital width & 18.5 & 13 & 16.1 & 21.4 & 18.7 \\
\hline Supraoccipital length & 36.7 & 13 & 31.0 & 40.6 & 36.1 \\
\hline
\end{tabular}


base of pectoral fin. Tip of outer mental barbels reaching middle pectoral-fin rays, almost to tip of pectoral spine. Gill membranes free, diverging just behind gular fold apex and supported by 7 branchiostegal rays. Gill rakers well-ossified, sharp and slender; 15-17 (mode $=15)$ on first branchial arch; 3-4 on epibranchial $($ mode $=3), 11-13$ on ceratobranchial $($ mode $=12 ; n=13)$. Dorsal fin rays II, 6 (mode $=6 ; n=13$ ); fin inserted near anterior onethird of SL, its origin slightly posterior to vertical through tip of innermost pectoral-fin ray. Spinelet narrow, sharply angular or having low anterior crest. Dorsal spine straight, strong, pungent, shorter than first branched ray, continued in filamentous ray reaching nearly to edge of first soft dorsal-fin ray; its length approximately equal to pectoral-spine length. Dorsal spine sometimes with 1 or 2 anterior distal serrae $(n=9)$. Posterior margin of dorsal spine with moderately sharp retrorse spines distally, becoming gradually erect near spine base. First branched dorsal-fin ray longest, last dorsal-fin ray less than one-half-length of first ray; distal margin of dorsal fin nearly straight. Adipose fin large, slightly posterior to middle of body. Adipose-fin margin rounded and moderately deep, its apex near to vertical through anal-fin origin, ending posteriorly as short free lobe to vertical through tip of last anal-fin ray. Caudal fin i, 7,8,i $(n=13)$ deeply forked, with pointed lobes; dorsal lobe slightly longer than ventral lobe, outer principal rays non-filamentous. Eighteen dorsal and 19 ventral procurrent caudal-fin rays. Anal fin inserted at posterior one-third of SL; fin margin slightly concave, not forming distinct lobe anteriorly; tips of longest anterior and posterior branched rays meet when depressed. Anal fin iv-v,7-8 (mode $=7 ; n=13)$, last rays simple, first and second branched rays longest. Pectoral fin i,9-10 (mode $=9 ; n=13)$; its posterior margin obliquely truncate; first soft ray longer than spine. Pectoral spine strong, continued in filamentous ray reaching nearly edge of first soft pectoral-fin ray. Pectoral spine distally pointed, dorsal and ventral surfaces smooth; numerous, regularly spaced, uniformly retrorse unicuspid dentations along most of posterior margin; anterior distal serrae weak or absent (larger in juveniles), antrorse and straight dentations along proximal half of anterior margin, becoming progressively less prominent and more crowded proximally; anterior dentations much larger in juveniles. Pelvic fin i,5 $(n=6)$; first branched ray longest, inserted near vertical through fifth and sixth branched dorsal-fin ray. Lateral-line canal complete, extending onto caudal-fin base; canal nearly straight, with superficial tubular ossicles directed posteroventrally and more developed anteriorly; no accessory laterosensory canals posterior to nuchal area. Posterior cleithral process broad, triangular, ventral margin nearly straight, dorsal margin somewhat concave; granular and osseous tubercles on lateral surface. Urogenital papilla short, located in shallow depression immediately posterior of anus. No apparent sexual dimorphism. Superficial ossifications of Weberian complex centrum not covering seventh centrum. Total vertebrae 41 ( 15 precaudal and 26 caudal). First pleural rib on sixth vertebra. Nine pairs of pleural ribs.

Color in alcohol. Body color grayish to yellowish. Ventral region brownish to light. Light narrow band along lateral line.
Head surface grayish to brownish. Eyes dark. Some specimens with several dark chromatophores on surface of posterior cleithral process, opercle and below orbit region; sometimes reaching body flanks; such chromatophores more concentrated on lower half of flanks below lateral line. Dorsal fin with black chromatophores on distal portion of rays 2-4. Pectoral, pelvic and anal fins hyaline, base sometimes yellowish. Adipose fin hyaline with minute uniformly scattered melanophores on distal portion. Black chromatophores along interradial membranes of caudal fin, concentrated on median portion of each caudal-fin lobe. Maxillary barbel dusky on dorsal surface; lighter on ventral surface. Mental barbels pale.

Distribution. Pimelodus halisodous is known from the upper and middle portions of the rio Tocantins drainage (Fig. 2).

Etymology. The specific name, halisodous from the Greek adjective halis, meaning in crowds, in plenty, sufficient, enough, plus the Greek noun odous, meaning tooth. The name alludes to the several ( $c a .15)$ irregular rows of conical and slender teeth on each premaxilla. A noun in apposition.

\section{Pimelodus joannis, new species}

Fig. 4

\section{Pimelodus sp. C - Lucinda et al., 2007: 79}

Holotype. MCP 41739, $51.0 \mathrm{~mm}$ SL, Ipueiras, rio Tocantins near the confluence with rio Manoel Alves, approximately $11^{\circ} 19^{\prime} \mathrm{S}$ 48³8'W, 20 Jan 1999, Neamb-UFT.

Paratypes. Brazil. Tocantins State. All collected by Neamb-UFT staff. MCP 41919, 5, 42.6-45.0 mm SL, and UNT 5641, 34 (1 c\&s), 36.2-54.5 mm SL, collected with the holotype. UNT 5644, 1, 53.6 mm SL, Paranã, rio Paranã, fazenda Traçadal, approximately $12^{\circ} 30^{\prime} \mathrm{S}$ 48²' 'W, 26 Mar 1998. UNT 5655, 15, 26.5-40.0 mm SL, Porto Nacional, rio Tocantins, $10^{\circ} 43^{\prime} 15^{\prime \prime S} 48^{\circ} 25^{\prime} 14^{\prime \prime W}, 14$ Dec 1999. UNT 5751, 1, 49.9 mm SL, Paranã, rio Paranã, fazenda Traçadal, approximately $12^{\circ} 30^{\prime} \mathrm{S} 48^{\circ} 12^{\prime} \mathrm{W}, 27 \mathrm{Mar} 1998$. UNT 5760, 1, $76.9 \mathrm{~mm}$ SL, Porto Nacional, córrego Narciso, approximately $10^{\circ} 43^{\prime} \mathrm{S} 48^{\circ} 24^{\prime} \mathrm{W}, 2$ Oct 2001. UNT 5790, 1, $39.1 \mathrm{~mm}$ SL, Pedro Afonso, rio Tocantins, near rio Sono, approximately $8^{\circ} 59^{\prime} \mathrm{S} 48^{\circ} 10^{\prime} \mathrm{W}, 15$ Jan 2001. UNT 8241, 1, $44.9 \mathrm{~mm}$ SL, Ipueiras, rio Tocantins near rio Manoel Alves, approximately $11^{\circ} 19^{\prime} \mathrm{S} 48^{\circ} 28^{\prime} \mathrm{W}, 20$ Jan 2000.

Diagnosis. Pimelodus joannis is distinguished from its congeners, except $P$. halisodous, $P$. jivaro, $P$. ornatus, $P$. pictus, and $P$. stewarti, by the presence of a dorsal median crest along supraoccipital process ( $v s$. crest absent); shorter distance between the posterior nostril and the anterior orbital border (posterior nostril closer to anterior orbital border $v s$. posterior nostril closer to anterior nostril than to anterior orbital border); a dark spot on the distal portion of dorsal-fin rays 2-4 (vs. no spot); and two dark blotches on the base of the caudal fin ( vs. absence of such spots). Pimelodus joannis differs from $P$. jivaro by having a shorter maxillary barbel, which extends only slightly past caudal-fin base ( $v s$. maxillary barbel extending beyond caudal-fin base); a dark spot in the distal portion of dorsal-fin rays 2-4 ( $v s$. absence of such 


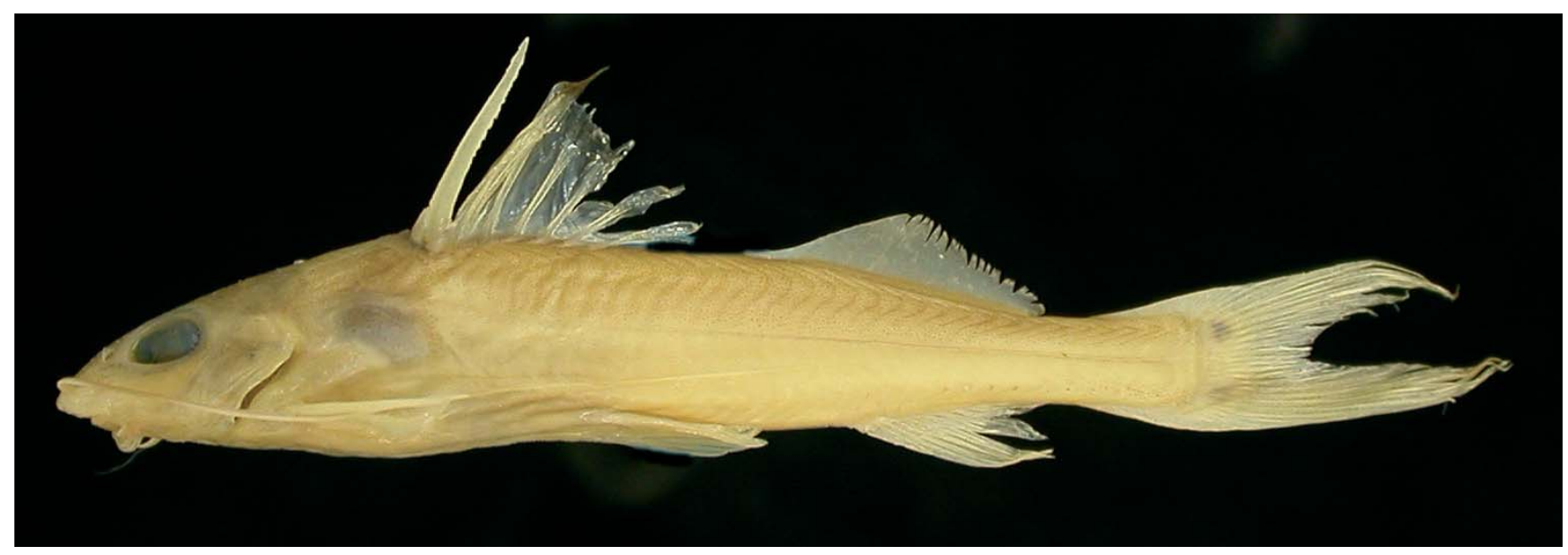

Fig. 4. Pimelodus joannis, holotype, MCP 41739, 51.0 mm SL, Ipueiras, rio Tocantins, Brazil.

spot); and two dark blotches on the base of the caudal-fin (vs. absence of such spots). The new species from P. ornatus and $P$. pictus by the uniform grayish to yellowish coloration (vs. presence of bands or dark dots along flanks, respectively). Pimelodus joannis differs from $P$. stewarti by having a shorter posterior cleithral process (10.2-12.4 vs. 12.7-15.6\% of SL); by the presence of two dark blotches on the caudal-fin base ( $v s$. absence of such dark blotches); and by the presence of a dorsal median crest along the supraoccipital process ( $v s$. no crest). Pimelodus joannis differs from $P$. halisodous by having a shorter pectoral-spine (15.5-18.5 vs. 20.0-23.5\% of SL); a shorter snout (35.8-41.8 vs. 43.1-47.9\% of HL); and by fewer premaxillary tooth rows (5-9 vs. 13-16).

Description. Morphometric data in Table 1. Body deeper than wide. Dorsal profile of body convex along snout; straight from orbital region to dorsal-fin origin, straight from dorsal insertion to adipose-fin origin, then gently sloping to anterior extent of caudal peduncle. Dorsal and ventral profiles of caudal peduncle slightly concave. Ventral profile of head straight to anterior region of isthmus; ventral profile of body slightly convex to anal-fin origin; anal-fin base straight. Head covered by thin skin. Skull roof ornamented with numerous small granulations, more visible in larger specimens. Snout projecting beyond mandibular symphysis by distance less than one internarial length. Mouth subterminal; margins curved in ventral view when mouth closed and exposing less than anterior half of premaxillary tooth rows; upper lip thick, fleshy, not striated. Fleshy rictal fold in pocket behind corner of mouth. Posterior nostrils closer to anterior orbital border than to anterior nostrils; anterior nostril with fleshy rim slightly raised posteriorly; posterior nostril thin, fleshy, rim elevated anteriorly. Eye large, elliptical, margin completely free and dorsolaterally positioned on head; horizontal orbital diameter greater than interorbital width; orbit oblong, horizontal orbital diameter greater than vertical orbital diameter. Premaxillary tooth patch short, broad, rectangular and transversely elongate; internal border of premaxillary tooth plate straight or slightly concave; premaxilla with eight irregular rows of slender conical teeth. Dentary with
5-9 tooth rows $(\mathrm{n}=10)$. Vomerine and pterygoid tooth-plate absent. Anterior cranial fontanel triangular in dorsal view, open from mesethmoid to frontals, and terminating anterior to vertical through posterior margin of eye. Posterior fontanel welldeveloped and elongate. Supraoccipital process wide; dorsal surface with longitudinal median crest; ornamented with numerous small granulations; lateral margins of supraoccipital process converging posteriorly, process covered by narrow sheath of opaque hyaline skin. Anterior and middle nuchal plates ornamented sparsely with tuberculated ridges. Anterior nuchal plate with conspicuous anterior process fitting into bifid supraoccipital tip; posterior nuchal plate with short posterior process not trespassing line through origin of first branched dorsal-fin ray. Three pairs of barbels, flattened at base. Maxillary barbel inserted at vertical through anterior edge of lower lip; surpassing caudal-fin base origin. Mental barbels inserted anterior to gular fold apex, in curved line parallel to mandibular margin. Inner mental barbel reaching base of pectoral fin. Tip of outer mental barbel reaching to pectoral spine. Gill membranes free, diverging just behind gular fold apex and supported by eight branchiostegal rays. Gill rakers well-ossified, sharp and slender; 11-16 (mode $=13$ ) on first branchial arch; 24 on epibranchial $($ mode $=3), 9-13$ on ceratobranchial $($ mode $=$ $11 ; n=52)$. Dorsal fin rays II, 6 (mode $=6 ; n=59)$; fin inserted near anterior one-third of SL; its origin slightly anterior to vertical through tip of innermost pectoral-fin ray. Spinelet narrow, sharply angular or exhibiting low crest anteriorly. Dorsal spine straight, strong, pungent, shorter than first branched ray, continued in filamentous ray reaching near the edge of the first soft dorsal-fin ray; approximately as long as the pectoral spine length. Dorsal spine with 1-3 anterior distal serrae $(n=11)$. Posterior margin of dorsal spine with moderately sharp retrorse spines distally, becoming gradually erect near spine base. First branched dorsal-fin ray longest, last dorsal-fin ray less than one-half-length of the first ray; distal margin of dorsal fin nearly straight. Adipose fin large, posterior to middle of body; its origin approximately on vertical through first branched pelvic-fin ray. Adipose-fin margin rounded and moderately deep, its apex near to vertical through base of rays 6-8 of anal fin, 
Table 3. Morphometric data of Pimelodus joannis. Range includes the holotype $(\mathrm{H})$.

\begin{tabular}{|c|c|c|c|c|}
\hline Measurements & $\mathrm{H}$ & $\mathrm{n}$ & low high & $\overline{\text { mean }}$ \\
\hline Standard length $(\mathrm{mm})$ & 51.0 & 21 & 38.776 .9 & 42.5 \\
\hline \multicolumn{5}{|c|}{ Percents of standard length } \\
\hline Predorsal length & 36.2 & & 35.237 .8 & 36.5 \\
\hline Preanal length & 72.4 & 21 & 70.074 .2 & 72.3 \\
\hline Head length & 26.5 & 21 & 25.327 .4 & 26.1 \\
\hline Caudal-peduncle length & 16.6 & 21 & 15.419 .3 & 17.1 \\
\hline Caudal-peduncle depth & 7.7 & 21 & $7.0 \quad 7.9$ & 7.5 \\
\hline Adipose-fin length & 29.4 & & 26.030 .8 & 28.6 \\
\hline Adipose-fin height & 6.5 & 21 & 5.67 .4 & 6.5 \\
\hline $\begin{array}{l}\text { End of dorsal-fin base to origin of adipose-fin } \\
\text { distance }\end{array}$ & 11.2 & 21 & 8.812 .9 & 10.5 \\
\hline Anal-fin base length & 13.1 & 21 & 11.714 .6 & 13.4 \\
\hline Anal-fin length & 15.5 & 21 & 14.516 .3 & 15.5 \\
\hline Pelvic-fin length & 12.9 & 21 & 12.914 .7 & 14.0 \\
\hline Dorsal-fin length & 20.8 & 21 & 18.821 .7 & 20.3 \\
\hline $\begin{array}{l}\text { Urogenital papilla to anal-fin-base origin } \\
\text { distance }\end{array}$ & 14.3 & 20 & 12.615 .8 & 14.2 \\
\hline Dorsal-spine length & 21.0 & 21 & 19.923 .1 & 21.1 \\
\hline Pectoral-spine length & 17.1 & 21 & 15.518 .5 & 17.5 \\
\hline Body depth & 19.8 & 21 & 17.023 .5 & 19.5 \\
\hline Body width & 16.4 & 21 & 15.617 .7 & 16.5 \\
\hline Posterior cleithral-process length & 12.4 & & 10.212 .4 & 11.3 \\
\hline \multicolumn{5}{|c|}{ Percents of head length } \\
\hline Head depth & 61.6 & & 57.766 .7 & 62.7 \\
\hline Interorbital width & 18.0 & & 17.622 .9 & 19.9 \\
\hline Snout length & 38.2 & 21 & 35.841 .8 & 37.6 \\
\hline Internarial length & 19.9 & 21 & 18.921 .7 & 20.3 \\
\hline Anterior internarial width & 14.5 & 21 & 14.216 .8 & 15.7 \\
\hline Posterior internarial width & 22.7 & 21 & 22.127 .0 & 24.7 \\
\hline Horizontal eye diameter & 30.7 & & 30.436 .2 & 32.8 \\
\hline Mouth width & 27.8 & & 27.835 .9 & 32.2 \\
\hline Supraoccipital width & 19.1 & 21 & 17.321 .7 & 19.4 \\
\hline Supraoccipital length & 29.0 & 21 & 28.134 .4 & 31.5 \\
\hline
\end{tabular}

ending posteriorly as short free lobe slightly posterior to vertical through tip of last anal-fin ray. Caudal fin deeply forked, with pointed lobes; dorsal lobe slightly longer than ventral lobe, principal rays non-filamentous (i,7,8,i; $\mathrm{n}=59)$; 19 dorsal and 20 ventral procurrent rays. Anal fin inserted on posterior one-third of SL; fin margin nearly straight, without distinct lobe anteriorly; tips of second and third branched rays longest; longest anterior and posterior branched rays meeting when depressed. Anal fin iv-vi,6-8 (mode $=7 ; \mathrm{n}=57$ ), first and second branched rays longest. Pectoral fin i,7-9 (mode $=8 ; n=59)$; its posterior margin obliquely truncate, first soft ray slightly longer than spine tip. Pectoral spine strong, distally pointed, dorsal and ventral surfaces smooth; numerous, regularly spaced, uniformly retrorse unicuspid dentations along most of posterior margin; anterior distal serrae weak or absent (commonly larger in juveniles), antrorse and straight dentations along proximal half of anterior margin, becoming progressively less prominent and more crowded proximally; anterior dentations much larger in juveniles. Pelvic fin i,5 $(n=11)$, first branched ray longest, inserted near vertical through last branched dorsal-fin ray; its posterior margin slightly rounded. Lateral-line canal complete, extending onto caudal-fin base; canal nearly straight, with superficial tubular ossicles directed posteroventrally and more developed anteriorly; no accessory laterosensory canals posterior to nuchal area. Posterior cleithral process broad, triangular, ventral margin nearly straight, dorsal margin somewhat concave; granular and osseous tubercles on lateral surface. Urogenital papilla short, located in shallow depression immediately posterior of anus. No apparent sexual dimorphism. Superficial ossifications of Weberian complex centrum not covering seventh centrum. Total vertebrae 40 (15 precaudal and 25 caudal). First pleural rib on sixth vertebra. Ten pairs of pleural ribs.

Color in alcohol. Body light brown to yellowish. Venter light to yellowish. Head surface with blackish areas. Eye dark. Some dark chromatophores on posterior cleithral process, opercle and below orbit. Dorsal fin with black spot on distal portion of rays 2-4. Pectoral, pelvic and anal fins hyaline. Black chromatophores along interradial membranes of caudal fin, concentrated on median portion of ventral lobe. Two dark blotches on base of caudal fin. Maxillary barbel dusky on dorsal surface; lighter on ventral surface. Mental barbels pale.

Distribution. Pimelodus joannis is known from the upper and medium portions of the rio Tocantins drainage (Fig. 2).

Etymology. The specific name joannis is a patronym for John Lundberg, in recognition of his many contributions to catfishes systematic.

\section{Discussion}

Pimelodus is a poorly-defined and presumably a paraphyletic assemblage of species (Lundberg \& Littmann, 2003). The species level taxonomy of Pimelodus is still poorly known as is the phylogenetic relationships within the genus and with other genera. Given that a cladistic definition (hypothesis of monophyly) of Pimelodus is not available, the traditional non-cladistic diagnosis of Eigenmann \& Eigenmann (1890) is still in use. Those authors defined Pimelodus by the following set of non-derived morphological characters: vomerine teeth arranged in small patches; pterygoid and palatine edentulous; frontal fontanel not extending posterior of orbit; broad posterior cleithral process without spines; and first dorsal-fin ray spinous, followed by six branched soft rays.

Several described species of pimelodids fit into the definition above. As a consequence, a large number of species are currently assigned to Pimelodus and several undescribed species would fit the current definition of the genus as well. This, combined with the wide intrageneric variability in morphology and color pattern, pose difficulties for a complete systematic revision of the genus.

The current knowledge on the intrageneric relationships within the Pimelodidae is still under investigation, with most genera (including Pimelodus) lacking a monophyletic hypothesis. In order to properly define Pimelodus with this kind of monophyletic approach, the relationships of related pimelodid genera, e.g. Cheirocerus, Iheringichthys, and Duopalatinus also needs careful review and study. This work goes beyond the scope of this paper.

Some authors have recently provided some insight into 
the relationships of smaller groups of the Pimelodidae (e.g. Lundberg \& McDade, 1986; Lundberg et al. 1991a, b; Lundberg \& Parisi, 2002). Lundberg et al. (1991b) delimited the subfamily Pimelodinae, with the genus Pimelodus included in their Pimelodus-group within the "Calophysus-Pimelodus clade", and described synapomorphies for this clade within the subfamily [thereafter, Lundberg \& Littmann (2003) raised the Pimelodinae of Lundberg et al. (1991b) to family rank, excluding the genus Conorhynchos]. The three species herein described exhibit the character states proposed as synapomorphic for the family Pimelodidae and for the "Calophysus-Pimelodus clade".

Following Lundberg et al. (1991b: fig. 12B), the synapomorphic character state supporting the monophyly of the Pimelodus-group is the presence of a sutural joint along the entire extension of the transverse processes of the fourth and fifth vertebrae. However, Lundberg \& Parisi (2002), reported a submarginal gap between the transverse processes of these vertebrae in small specimens and in some other members of the Pimelodidae (e.g. Pimelodus ornatus, P. grosskopfii, and Duopalatinus). As a consequence, and given this character variation is not satisfactorily understood, we regard the three new species described herein as members of the Pimelodus-group (see Figs. 5-6).

An extensive posterior development of the superficial ossification of the Weberian complex centra that ventrally covers the seventh centrum was proposed by Lundberg et al. (1991b) as synapomorphic for a clade (within the Pimelodus-group)

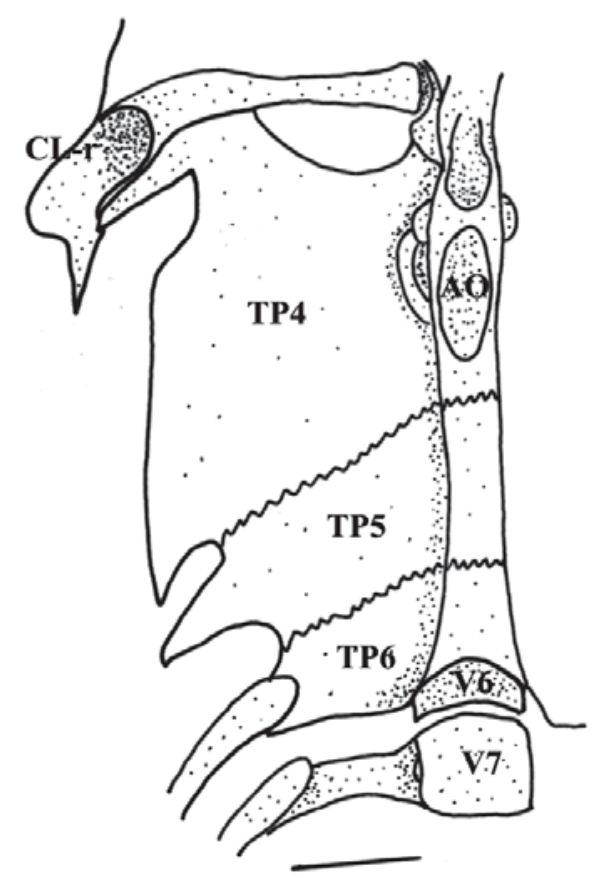

Fig. 5. Pimelodus halisodous, UNT 3438, 98.9 mm SL. Ventral view of left side of Weberian complex, basioccipital region and upper shoulder girdle. AO = aortic groove; CL-r = "cleithral ring"; TP4- $6=$ transverse process of vertebrae 4 to 6 ; V6-7 $=$ vertebrae 6 and 7 . Scale bar $=1 \mathrm{~mm}$. composed of Pimelodus, Cheirocerus, Duapalatinus, Exallodontus, Iheringichthys, and Parapimelodus. Our three new species do not exhibit this condition. Instead, each has centrum 7 exposed ventrally and the superficial ossification is restricted to more anterior vertebrae (Figs. 5-6). It is important to emphasize that this character exhibits different ontogenetic states, including an exposed seventh vertebral centrum (Azpelicueta, 2001; Ribeiro \& Lucena, 2006b).

Lundberg et al. (1991b), and Lundberg \& Parisi (2002) also identified one derived state of the trigeminofacial nervecomplex (and respective foramina), which diagnoses a group of Pimelodus species, including P. maculatus (type-species). This character state is also exhibited by species of some other nominal pimelodid genera (e.g. Iheringichthys and Bergiara) and is absent in some species currently assigned to the genus Pimelodus (e.g. P. ornatus and P. altissimus).

Although the three new species described herein lack the derived diagnostic characteristics for the above mentioned group, in the absence of a cladistic definition of the genus and a more comprehensive phylogenetic hypothesis for the group, we opted to describe them as new species of Pimelodus in keeping with the current definition of the genus proposed by Eigenmann \& Eigenmann (1890). Given these circumstances, one may question the wisdom of describing three species of such an unstable genus, as opposed to deferring such species descriptions until generic relationships are completely resolved. We argue that the descriptions of such new species are important since (1) these actions make species names available; (2)

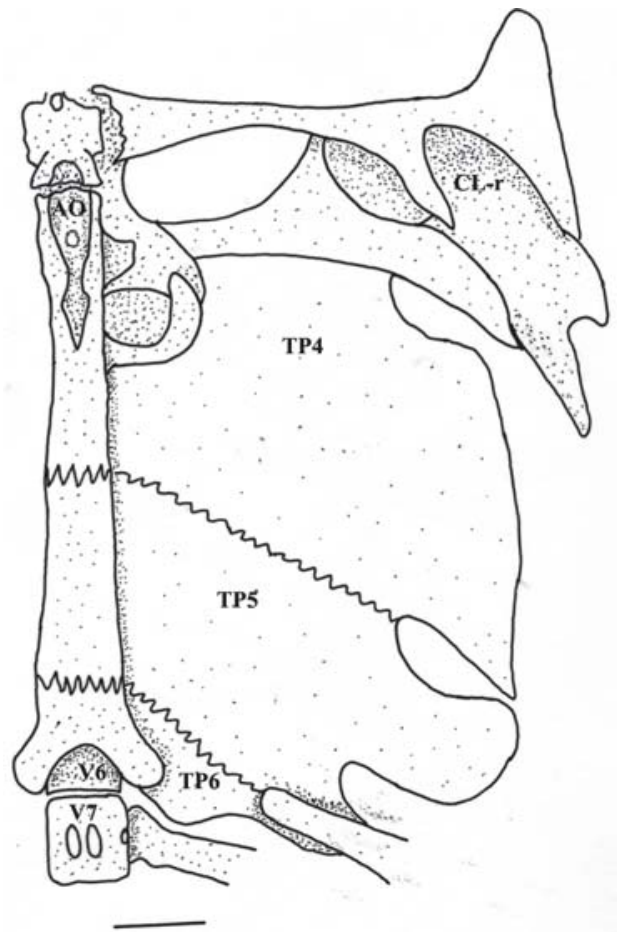

Fig. 6. Pimelodus joannis, UNT 5641, $54.0 \mathrm{~mm}$ SL. Ventral view of right side of Weberian complex, basioccipital region and upper shoulder girdle. AO = aortic groove; CL-r = "cleithral ring"; TP4-6 = transverse processes of vertebra 4 to 6 ; V6-7 $=$ vertebrae 6 and 7 . Scale bar $=1 \mathrm{~mm}$. 
they contribute to knowledge of the biodiversity within higherlevel clades, (3) they provide additional published information useful in the future resolution of generic relationships, and (4) these species are seriously threatened by severe alterations from the installation of hydroelectric plants in the middle and upper rio Tocantins basin (Lucinda et al., 2007).

Three additional species have been reported from the rio Tocantins drainage: Pimelodus blochii; P. ornatus; and P. tetramerus. Pimelodus ornatus and $P$. tetramerus possess a unique color pattern, consisting of dark bands along the sides of the body, which allows for quick recognition and distinction from the three new species herein described. Eigenmann (1912) described two varieties of Pimelodus blochii from the Amazon basin. His variety A, had only a gray ground coloration, and his variety B had black bands along the flanks. Pimelodus joannis, $P$. halisodous and $P$. stewarti exhibit a color pattern similar to that of variety A, but they differ from it by the possession of a larger distance between anterior and posterior nostrils (18.1-22.9\% HL vs. 11.6-16.9\% HL); a dark spot in the distal portion of dorsal-fin rays 2-4 in $P$. joannis and $P$. stewarti ( $v s$. absence of such spot); and by the presence of a dorsal median crest along the supraoccipital process in P. halosodous and P. joannis (vs. no crest).

The ichthyofauna of the rio Tocantins drainage is poorly known, especially in the middle and upper portions of this basin. This area contains a large proportion of endemic species for several Neotropical freshwater fish groups. Several new species have been described from this basin during the last few decades. Nonetheless, many species remain unknown to science, exhibit serious taxonomic problems or await formal description. All these facts indicate the poor level of taxonomic knowledge of this ichthyofauna and the need of additional sampling and taxonomic research.

Additional Examined Specimens. Pimelodus britskii: FMNH 105098, Holotype, PH (published photograph or illustration with reference) (Garavello \& Shibatta, 2007: fig. 4), Brazil, Paraná, rio Iguaçu, União da Vitória; MZUSP 50037, paratype, PH (Garavello \& Shibatta, 2007: fig. 5), Brazil, Paraná, rio Iguaçu, Quedas do Iguaçu. Pimelodus pantaneiro: MZUSP 87808, Holotype, PH (Souza-Filho \& Shibatta, 2007: fig. 2A), Brazil, Mato Grosso do Sul, rio Paraguay, rio Miranda, Bonito; MZUEL 3567, Paratype, PH (Souza-Filho \& Shibatta, 2007: fig. 2B), Brazil, Mato Grosso, rio Paraguay, rio Cuiabá, Poconé. Pimelodus pintado: ZVC P 6482, Holotype, PH (Azpelicueta et al., 2008: figs. 2A and 3A), Uruguay, Departamento Rocha, MerínPatos System, río Cebollatí; ANSP 54060, Paratype, PH (Azpelicueta et al., 2008: fig. 2B), Uruguay, Departamento Cerro Largo.

\section{Acknowledgements}

We thank Osvaldo Oyakawa and José Lima de Figueiredo (MZUSP) for the loan of specimens and for the support given to FRVR during his visit to MZUSP. We are grateful to Tiago Carvalho (MCP) for the holotype photographs. This paper was greatly improved by the suggestions of two anonymous reviewers. This study was partially supported by the "All Catfish Species Inventory Project - ACSP” (grant to FRVR, proc. NFS-DEB 0315963). CASL and PHFL are both partially supported by CNPq (processes 304366/2006-4 and 304838/2005-5, respectively).

\section{Literature Cited}

Azpelicueta, M. 2001. A new species of Pimelodus (Siluriformes: Pimelodidae) from the upper Paraná basin, Brazil. Ichthyological Exploration of Freshwaters, 12(3): 193-200.

Eigenmann, C. H. 1912. The fresh-water fishes of British Guiana, including a study of the ecological grouping of species, and the relation of the fauna of the plateau to that of the lowlands. Memoirs of the Carnegie Museum, 5(67): 1-578.

Eigenmann, C. H. \& R. S. Eigenmann. 1890. A revision of the South America Nematognathi or catfishes. Occasional Papers of the California Academy of Sciences, 1(2): 1-508.

Eschmeyer, W. N. 2007. The catalog of fishes on line (On-Line Version, Updated 9 Oct 2007) http://www.calacademy.org/research/ ichthyology/catalog/fishcatsearch.html accessed 16 Nov 2007.

Ferraris Jr., C. 2007. Checklist of catfishes, recent and fossil (Osteichthyes: Siluriformes), and catalogue of siluriform primary types. Zootaxa, 1418: 1-628.

Lucinda, P. H. F., I. S. Freitas, A. B. Soares, E. E. Marques, C. S. Agostinho \& R. J. Oliveira. 2007. Fish, Lajeado Reservoir, rio Tocantins drainage, State of Tocantins, Brazil. Check List, 3(2): $70-83$.

Lundberg, J. G., A. H. Bornbusch \& F. Mago-Leccia. 1991a. Gladioglanis conquistador N. Sp. from Ecuador with diagnoses of the subfamilies Rhamdiinae Bleeker and Pseudopimelodinae N. Subf. (Siluriformes: Pimelodidae). Copeia, 1991: 190-209.

Lundberg, J. G. \& M. W. Littmann. 2003. Family Pimelodidae (Longwhiskered catfishes). Pp. 432-446. In: Reis, R. E., S. O. Kullander \& C. J. Ferraris Jr. (Eds.). Check List of the Freshwater Fishes of South and Central America. Porto Alegre, Edipucrs, 729p.

Lundberg, J. G. \& K. Luckenbill. 2007. [Pimelodus maculatus: dry skeleton images.] http://catfishbone.acnatsci.org/Pimelodidae/ Pimelodus/maculatus/dry.skeleton.html accessed 22 Oct 2007.

Lundberg, J. G., F. Mago-Leccia \& P. Nass. 1991b. Exallodontus aguanai, a new genus and species of Pimelodidae (Pisces: Siluriformes) from deep river channels of South America, and delimitation of the subfamily Pimelodinae. Proceedings of the Biological Society of Washington, 104(4): 840-869.

Lundberg, J. G. \& L. A. McDade. 1986. On the South American catfish Brachyrhamdia imitator Myers (Siluriformes, Pimelodidae), with phylogenetic evidence for a large intrafamilial lineage. Notulae Naturae, 463: 1-24.

Lundberg, J. G. \& B. M. Parisi. 2002. Propimelodus new genus, and redescription of Pimelodus eigenmanni Van der Stigchel 1946, a long-recognized yet poorly-known South American catfish (Pimelodidae: Siluriformes). Proceedings of the Academy of Natural Science, 152: 75-88.

Ribeiro, F. R. V. \& C. A. S. Lucena 2006a. A new species of Pimelodus LaCépède, 1803 Siluriformes: Pimelodidae) from the rio São Francisco drainage, Brazil. Neotropical Ichthyology, 4(4): 411-418.

Ribeiro, F. R. V. \& C. A. S. Lucena. 2006b. Nova espécie de Pimelodus (Siluriformes, Pimelodidae) dos rios Tapajós e Tocantins, Brasil. Iheringia, série Zoologia, 96: 321-327.

Ribeiro, F. R. V. \& C. A. S. Lucena. 2007. Pimelodus microstoma Steindachner, 1877, a valid species of pimelodid catfish (Siluriformes: Pimelodidae) from the upper rio Paraná drainage. Neotropical Ichthyology, 5(1): 75-78.

Taylor, W. R. \& G. C. Van Dyke. 1985. Revised procedures for staining and clearing small fishes and other vertebrates for bone and cartilage study. Cybium, 9: 107-119.

Accepted August, 2008

Published September 30, 2008 